(๔) 2018 - ISSN 1807-2577

\title{
Fracture strength of monocrystalline and polycrystalline ceramic brackets during archwire torque
}

\author{
Resistencia à fratura de braquetes cerâmicos \\ Társio Caleb Bernardon KIELINGa ${ }^{\mathbb{D}}$, Lourenço CORRER-SOBRINHO ${ }^{\mathrm{b}} \mathbb{( 1 )}$, \\ Ana Paula Terossi de GODOI ${ }^{\mathfrak{D}}$, Carolina Carmo de MENEZES ${ }^{a}{ }^{(0)}$, Giovana Cherubini VENEZIANa ${ }^{(0)}$, \\ Ana Rosa COSTA ${ }^{\mathrm{a}, \mathrm{b} *}$ (1) \\ aUNIARARAS/FHO - Fundação Hermínio Ometto, Departamento de Ortodontia, Araras, SP, Brasil \\ bUNICAMP - Universidade Estadual de Campinas, Faculdade de Odontologia de Piracicaba, Departamento de \\ Odontologia Restauradora, Piracicaba, SP, Brasil
}

\begin{abstract}
How to cite: Kieling TCB, Correr-Sobrinho L, Godoi APT, Menezes CC, Venezian GC, Costa AR. Fracture strength of monocrystalline and polycrystalline ceramic brackets during archwire torque. Rev Odontol UNESP. 2019;48:e20190048. https://doi.org/10.1590/1807-2577.04819
\end{abstract}

\begin{abstract}
Resumo
Introdução: A demanda por tratamentos estéticos tem crescido nos últimos anos, sendo cada vez mais forte a preocupação com a estética por parte dos pacientes que buscam o tratamento ortodôntico. Objetivo: Este estudo avaliou a resistência à fratura de bráquetes cerâmicos monocristalinos e policristalinos de diferentes fabricantes quando submetidos ao torque do fio. Material e método: Sessenta bráquetes cerâmicos (Roth, incisivos centrais superiores direito, canaleta $0,022 \times 0,028$ polegadas) foram divididos em 2 grupos (30 espécimes por grupo) de acordo com o tipo da cerâmica: monocristalina e policristalina. Posteriomente estes grupos foram divididos em 3 sub-grupos $(n=10)$ de acordo com o fabricante: Orthometric, Eurodonto e Ortho Technology. Segmentos de fio de aço inoxidável retangular $(0,019$ x 0,025 polegadas) foram dobrados em forma de " $U$ ", sendo que a base do " $U$ " foi inserida na canaleta do bráquete e fixado com fio de amarilho em aço inoxidável $(0,008 \mathrm{~mm})$. Nas extremidades do "U" foram realizadas dobras verticais para servir de apoio para o cinzel da máquina de ensaio universal Instron. 0 ensaio de resistência à fratura foi realizado à velocidade de $1,0 \mathrm{~mm} / \mathrm{min}$ até ocorrer a fratura. Os dados foram registrados, transformados em g.mm e submetidos à ANOVA dois fatores e ao teste de Tukey (SAS Institute Inc., Cary, NC, USA, version 9.3) ( $\alpha=5 \%$ ). Resultado: Os bráquetes monocristalinos apresentaram maior resistência à fratura em relação aos policristalinos, independente do fabricante $(\mathrm{p}<0,05)$. Os maiores valores de resistência à fratura foram obtidos com os bráquetes da Ortho Technology e Orthometric, os quais não diferiram estatisticamente entre si $(p>0,05)$. Conclusão: Bráquetes monocristalinos possuem maior resistência à fratura em relação aos policristalinos com diferenças na resistência à fratura entre os diferentes fabricantes.
\end{abstract}

Descritores: Bráquetes cerâmicos; resistência à fratura; torção; torque.

\begin{abstract}
Introduction: In recent years, there has been an increasing demand for esthetic treatments, especially among orthodontic patients. Objective: This study determined the fracture strength of monocrystalline and polycrystalline ceramic brackets of different manufacturers during archwire torque. Material and method: Sixty ceramic brackets (Roth, right upper central incisors, $0.022 \times 0.028$-inch slot) were allocated into two groups (30 specimens per group) according to the type of ceramics: monocrystalline and polycrystalline. Subsequently, the groups were divided into three subgroups $(n=10)$ according to the manufacturer: Orthometric, Eurodonto and Ortho Technology. Sixty PVC cylinders were filled with chemically activated acrylic resin (CAAR), the brackets were fixed with CAAR onto the cylinder surface and the excess material was used to partially cover the base of the bracket. After $24 \mathrm{~h}$, the U-shaped wire base ( $0.019 \times 0.025$ inches; $6 \mathrm{~mm}$ height and width) was inserted into the bracket slot and fixed thereon
\end{abstract}


with a stainless-steel wire. Vertical folds were made at the ends of the " $U$ " to support the universal test machine chisel. The fracture strength test was performed at a speed of $1.0 \mathrm{~mm} / \mathrm{min}$ until fracture into a universal test machine (Instron). The data were recorded, transformed into g.mm and submitted to two-way ANOVA followed by Tukey's post-hoc test (SAS Institute Inc., Cary, NC, USA, version 9.3) ( $\alpha=5 \%$ ). Result: Monocrystalline brackets showed a higher fracture strength than polycrystalline brackets, regardless of the manufacturer $(\mathrm{p}<0.05)$. The highest fracture strength values were observed in Ortho Technology and Orthometric brackets, with no significant difference between them $(p>0.05)$. Conclusion: Monocrystalline ceramic brackets have a higher fracture strength than polycrystalline brackets, with significant manufacturer-dependent differences.

Descriptors: Ceramic brackets; fracture strength; torsion; torque.

\section{INTRODUCTION}

In recent years, there has been an increasing demand for esthetic treatments, especially among orthodontic patients ${ }^{1}$. Polycarbonate brackets were the first of this kind to be commercialized $^{2}$. However, they did not have adequate mechanical behavior, presented color alterations, limited adhesiveness, low dimensional stability and a higher coefficient of friction when in contact with metallic wires ${ }^{3}$. To overcome these shortcomings, ceramic brackets were introduced in the dental market in the late $1980 \mathrm{~s}^{4}$.

Ceramic brackets are composed of aluminum oxide $\left(\mathrm{Al}_{2} \mathrm{O}_{3}\right)$, with a monocrystalline (composed of a single $\mathrm{Al}_{2} \mathrm{O}_{3}$ crystal) or polycrystalline (multiple $\mathrm{Al}_{2} \mathrm{O}_{3}$ crystals) structure fused at high temperatures ${ }^{5}$. Previous studies have shown that monocrystalline ceramic brackets have a higher fracture strength and translucency than polycrystalline brackets ${ }^{4,6,7}$. On the other side, monocrystalline brackets have a high production cost and manufacturing difficulty ${ }^{8}$. The manufacturing process plays an important role in the clinical performance of ceramic brackets as well as does the presence of pores, machining and propagation of cracks which may induce fracture of the bracket ${ }^{9}$.

While there is currently a great range of prescriptions available to the orthodontist ${ }^{10}$, including prescriptions customized for each case ${ }^{11}$, one should still apply archwire torsion forces to obtain the desire torque ${ }^{12,13}$. Some studies have shown that the application of high torque (third-order folds) can fracture ceramic brackets ${ }^{7,14-16}$. However, such type of fracture is less recurrent with the application of second-order folds, unless the bracket has been weakened by direct trauma and/or by the manufacturing method. Ceramics have high friability (no plastic deformation), but also have a high resistance to weariness and corrosion and excellent optical properties $^{6}$. Several factors can influence the torque during orthodontic mechanics, which include the torsion magnitude, wire composition and thickness, slot size and depth, vertical positioning, and bracket 17,18 .

This phenomenon occurs more frequently in anterior teeth ${ }^{10,16}$ and at the base of the bracket wings, where most tension is present, due to archwire torsion forces inside the slot ${ }^{19}$. The addition of wires and accessories may induce the development and propagation of cracks in the brackets ${ }^{19}$. Hence, the presence of fractures in orthodontic accessories may affect treatment efficiency and length, cause discomfort to the patient, and increase their risk of aspirating or swallowing bracket fragments ${ }^{20}$.

The mechanical behavior of monocrystalline and polycrystalline ceramic brackets has been previously investigated ${ }^{4,6,7}$. Nevertheless, there are no reports in the literature on the fracture strength of these types of brackets from the same manufacturer during archwire torsion (third-order fold), in close contact with the bracket slot at a $6-\mathrm{mm}$ distance. Thus, the present study determined the fracture strength of monocrystalline and polycrystalline ceramic brackets of different manufacturers during archwire torque. The null hypotheses tested in the present study were that (i) there are no difference on the fracture strength of monocrystalline and polycrystalline 
ceramic brackets; and that (ii) there are no difference on the fracture strength among the different brands.

\section{MATERIAL AND METHOD}

\section{Specimen Preparation}

Sixty PVC cylinders (Tigre do Brazil, Joinville, SC, Brazil) were filled with chemically activated acrylic resin (CAAR, Jet Set; Clássico Artigos Odontológicos Ltda, São Paulo, SP, Brazil) according manufacture's recommendations. After polymerization, micro-retentions were created on the CAAR cylinder surface with silicon carbide sandpaper no. 220 (Norton ${ }^{\circledR}$ SA, São Paulo, SP, Brazil) for $1 \mathrm{~min}$. The brackets were fixed with CAAR onto the cylinder surface and the excess material was used to partially cover the base of the bracket, so that to create an extra retention and avoid bracket detachment during the mechanical testing. Stainless-steel wire segments (0.019 x 0.025 inches) (Gac Orthomax, Matão, São Paulo, Brazil) were folded with pliers no. 139 (Dentaurum Inc. Langhorne, USA) into a U-shape with $6 \mathrm{~mm}$ height and width (Figure 1B). After 24h, the base of the U-shaped wire was inserted into the bracket slot and fixed thereon with a 0.008-mm wire (Gac Orthomax, Matão, São Paulo, Brazil). The curves were juxtaposed with the bracket wings, and a vertical curvature was made $6 \mathrm{~mm}$ from the bracket to be used as a support for the test machine chisel (Figures 1A and 1B) 7 .

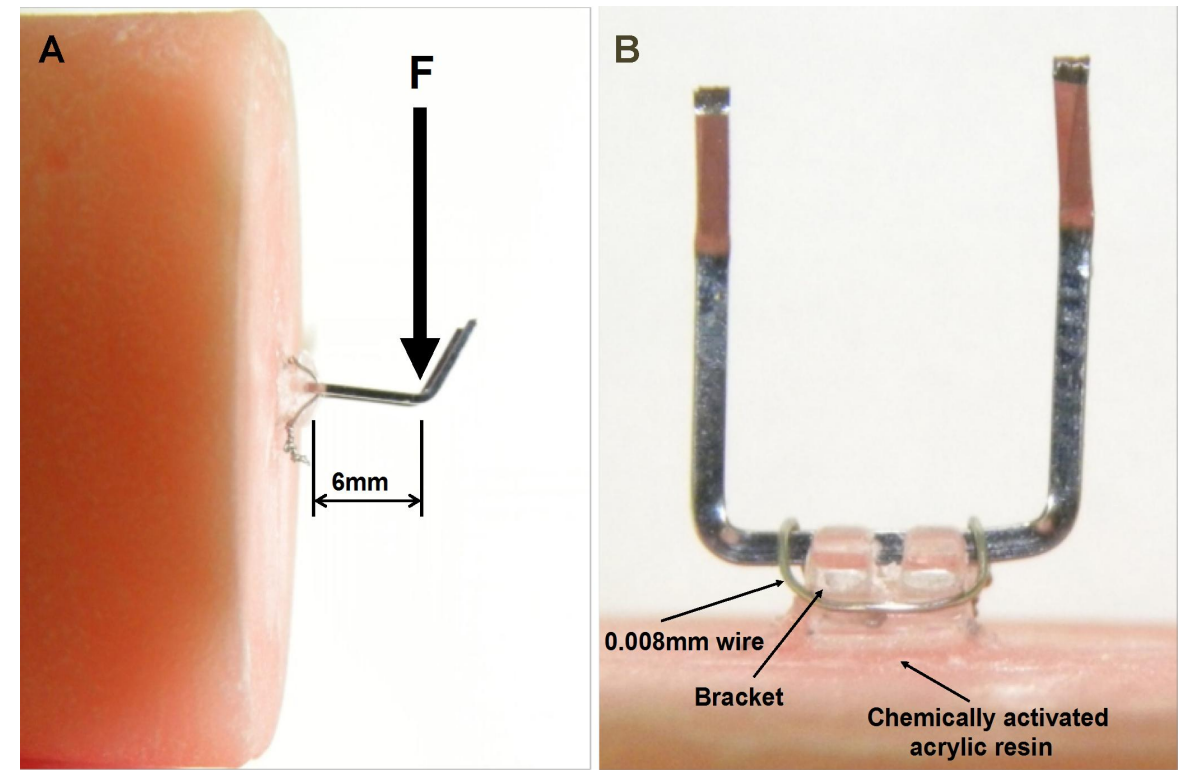

Figure 1. A. Insertion of the U-shaped wire base into the ceramic bracket slot and fixation there on with a metallic wire. B. U-shaped steel wires $(0.019 \times 0.025$ inches). The torsion forces were recorded in grams $(\mathrm{g})$ and the fracture strength data were transformed into g.mm using the formula $t=F x d$, where $F$ is the force in grams and $d$ is the distance $(\mathrm{mm})$ between the point of force and the bracket slot $(\mathrm{d}=6 \mathrm{~mm})$. In this test, the wire was pushed down by the machine chisel to simulate a buccal torque ${ }^{7}$.

Sixty ceramic brackets (Roth prescription, right upper central incisors, $0.022 \times 0.028$ inches) were divided into two groups (30 specimens per group) according to the ceramic composition: monocrystalline and polycrystalline. These were allocated into three subgroups $(n=10)$ according to the manufacturer: Orthometric (Marília, SP, Brazil), Eurodonto (Curitiba, Paraná, Brazil) and Ortho Technology (Tampa, Florida, USA). 


\section{Fracture Strength Test}

The ceramic brackets were submitted to a fracture strength test. Briefly, the acrylic cylinder was fitted into a universal test machine (Instron; Model 4411, Canton, MA, USA) with the cervical wings positioned perpendicular to the ground and the machine chisel supported by the wire curvatures (Figure 1A - the red arrow represents the machine chisel). The folds in the wire served as a stop and a support so that the chisel would not slide during the test (Figure 1B). The fracture strength test was performed at a speed of $1.0 \mathrm{~mm} / \mathrm{min}$ until fracture. The torsion forces were recorded in grams (g) and the fracture strength data were transformed into g.mm using the formula $\mathrm{t}=f \mathrm{x} d$, where $f$ is the force in grams and $d$ is the distance (mm) between the point of force and the bracket slot $(d=6 \mathrm{~mm})$. In this test, the wire was pushed down by the machine chisel to simulate a buccal torque ${ }^{7}$. After exploratory analysis of the data and verification of a normal distribution, the data were submitted to two-way Analysis of Variance (ANOVA) followed by Tukey's post-hoc test (SAS Institute Inc., Cary, NC, USA, version 9.3) $(\alpha=5 \%)$.

\section{RESULT}

The findings of our study are described in Table 1. The analysis of variance indicated a significant two-way interaction between the ceramic bracket and the manufacturer $(p<0.0001)$. Monocrystalline ceramic brackets showed a higher fracture strength (g.mm) than polycrystalline brackets, regardless of the manufacturer $(p<0.05)$.

Table 1. Mean (standard deviation) fracture strength values (in g. $\mathrm{mm}$ ) of monocrystalline and polycrystalline ceramic orthodontic brackets from different manufacturers

\begin{tabular}{|c|c|c|c|c|c|c|c|c|}
\hline \multirow{3}{*}{$\begin{array}{c}\text { Manufacturer } \\
\text { Orthometric }\end{array}$} & \multicolumn{8}{|c|}{ Ceramic Orthodontic Bracket } \\
\hline & \multicolumn{4}{|c|}{ Monocrystalline } & \multicolumn{4}{|c|}{ Polycrystalline } \\
\hline & 8,881 & $(2,372)$ & $\mathrm{a}$ & A & 4,507 & (521) & $\mathrm{a}$ & B \\
\hline Eurodonto & 6,109 & $(678)$ & $\mathrm{b}$ & A & 3,830 & $(890)$ & $\mathrm{b}$ & B \\
\hline Ortho Technology & 9,308 & $(2,259)$ & $\mathrm{a}$ & A & 5,042 & $(770)$ & $\mathrm{a}$ & B \\
\hline
\end{tabular}

Different lowercase letters in the columns indicate significant differences between the manufacturers for each type of bracket $(p<0.05)$. Different capital letters in the lines indicate significant differences between the bracket types of the same manufacturer $(p<0.05)$.

The fracture strength of Ortho Technology and Orthometric brackets was found to be significantly higher than that of Eurodonto brackets $(p<0.05)$ for both monocrystalline and polycrystalline compositions. No significant difference was observed between Ortho Technology and Orthometric brackets ( $p>0.05)$, regardless of the bracket type.

\section{DISCUSSION}

In the present study, monocrystalline ceramic brackets showed a significantly higher fracture strength than polycrystalline brackets, which is in line with the reports by Vhanbatte et al. ${ }^{15}$. Thus, the first null hypothesis that there are no difference on the fracture strength of monocrystalline and polycrystalline ceramic brackets was rejected. Although both brackets are composed of alumina oxide, the monocrystalline ones have a single crystal of alumina in their composition whereas polycrystalline brackets have several small crystals of alumina. In addition, there are significant differences in the manufacturing process of both types of brackets. 
Polycrystalline brackets are manufactured from the mixture of aluminum oxide particles with the use of an agglutinative substance, so that it is molded and then cut to the final shape of the bracket. The mixture is heated to temperatures above $1800{ }^{\circ} \mathrm{C}$ in order to burn the agglutinative substance and thereby bind the aluminum oxide particles. The bracket undergoes a heat treatment with the purpose of removing surface imperfections and reducing the structural stresses created during cutting ${ }^{21}$. This molding process has the disadvantage of the presence of structural imperfections or impurities around the grains, which could generate a region susceptible to crack propagation once the material is under tension ${ }^{22}$.

In contrast, monocrystalline brackets are processed through a molten mass of aluminum oxide, which is subjected to temperatures above $2100^{\circ} \mathrm{C}$, thereby yielding individual crystals of sapphire. Next, this mass is cooled down slowly to better control the crystallization process. This procedure is necessary to obtain a pure crystal and to eliminate almost completely the possibility of fracture propagation through areas that contain imperfections or impurities 9 . Hence, the manufacturing process plays a significant role in the performance of ceramic brackets, as the binding of small crystals of alumina at high temperatures may potentially create surface pores and gaps which may compromise the fracture strength of the bracket.

The fracture strength of Ortho Technology and Orthometric brackets was statistically greater to that of Eurodonto brackets, regardless of the ceramic composition. Therefore, the second null hypothesis was also rejected. Previous studies ${ }^{6,14,23}$ reported that the ideal momentum on a central upper incisor varied from 1035 to 2373 g.mm. On the other hand, Nikolai ${ }^{24}$ (1985) observed that the momentum generated in the ideal torque on the upper incisor should range between 3,000 and 3,500 g.mm. Thus, the momentum interval required to perform a successful torque on the upper incisors ranges from 1,035 to 3,500 g.mm. Although the Eurodonto ceramic brackets had a statistically lower fracture strength as compared to the other two manufacturers, the Eurodonto polycrystalline bracket showed the lowest fracture strength among all studied brackets and yet exhibited a strength of 3,830 (890) $\mathrm{mm}$ (Table 1). Therefore, our results indicated that the fracture strength measurements of all orthodontic brackets tested in the current study (Table 1) presented enough resistance to withstand the torque on the upper incisors. These findings indicate that the brackets tested herein can satisfactorily withstand the efforts applied during orthodontic treatment.

There is a great variability in the experimental designs reported in the literature in relation to bracket slot size and/or type, rectangular steel wire size and/or type, type of prescription with the insertion of different torques and/or angulation, and to the manufacturing process. These parameters may be responsible for the inconsistent published results and make it difficult to compare our findings with those of the literature. Moreover, it is worth noting that the use of very thick rectangular steel wires with third-order folds fixed with metallic wires can generate a high structural tension, which can totally or partially fracture the bracket structure ${ }^{22}$. Further studies should consider saliva storage and/or temperature variation in the oral cavity over time in an attempt to reproduce what happens clinically. Lastly, the microstructural aspects of ceramic brackets as well as their fracture profile should be further addressed by scanning electron microscopy (SEM) analysis or other more sophisticated microscopic approaches.

Within the limitations of this in vitro study, it can be concluded that (1) monocrystalline ceramic brackets have a higher fracture strength than polycrystalline brackets; and that (2) the fracture strength of Eurodonto brackets was lower than that of Ortho Technology and Orthometric brackets, regardless of the type of ceramics (monocrystalline or polycrystalline). 


\section{REFERENCES}

1. Rosvall MD, Fields HW, Ziuchkovski J, Rosenstiel SF, Johnston WM. Attractiveness, acceptability, and value of orthodontic appliances. Am J Orthod Dentofacial Orthop. 2009 Mar;135(3):276.e1-12, discussion 276-7. http://dx.doi.org/10.1016/j.ajodo.2008.07.011. PMid:19268820.

2. Newman GV. Adhesion and orthodontic plastic attachments. Am J Orthod. 1969 Dec;56(6):573-88. http://dx.doi.org/10.1016/0002-9416(69)90193-6. PMid:5260045.

3. Alkire RG, Bagby MD, Gladwin MA, Kim H. Torsional creep of polycarbonate orthodontic brackets. Dent Mater. 1997 Jan;13(1):2-6. http://dx.doi.org/10.1016/S0109-5641(97)80001-2. PMid:9467316.

4. Araújo MD, Grande RM, Yoshimura HN. Microestrutura e propriedades mecânicas de bráquetes cerâmicos. Journal of Biodentistry and Biomaterials. 2013;2:11-26.

5. Jena AK, Duggal R, Mehrotra AK. Physical properties and clinical characteristics of ceramic brackets: a comprehensive review. Trends Biomater Artif Organs. 2007 Jan;20(2):101-15.

6. Babaji P, Shivaprakash S, Dmello K, Kamble SS, Ajith S, Gowda AR. An in vitro comparison of resistance to second and third order archwire activations of three different varieties of esthetic brackets. Indian J Dent Res. 2013 Nov-Dec;24(6):701-7. http://dx.doi.org/10.4103/0970-9290.127615. PMid:24552930.

7. Manhães FR, Divino R, Lucato AS, Vedovello SAS, Correa CA, Valdrighi HC. Fracture strength of ceramic brackets submitted to arch wire torsional strain. Braz J Oral Sci. 2011 Jul/Sep;10(3):180-3.

8. Lopes H Fo, Maia LE, Araújo MV, Ruellas AC. Influence of optical properties of esthetic brackets (color, translucence, and fluorescence) on visual perception. Am J Orthod Dentofacial Orthop. 2012 Apr;141(4):460-7. http://dx.doi.org/10.1016/j.ajodo.2011.10.026. PMid:22464528.

9. Sobreira CR, Loriato LD, Oliveira DD. Bráquetes estéticos: características e comportamento clínico. Rev Clin Ortodon Dental Press. 2007 Fev-Mar;6(1):94-102.

10. Lacarbonara M, Accivile E, Abed MR, Dinoi MT, Monaco A, Marzo G, et al. Variable Torque Prescription: State of Art. Open Dent J. 2015 Jan;9(1):60-4. http://dx.doi.org/10.2174/1874210601509010060. PMid:25674173.

11. Johnson E. Selecting custom torque prescriptions for the straight-wire appliance. Am J Orthod Dentofacial Orthop. 2013 Apr;143(4 Suppl):S161-7. http://dx.doi.org/10.1016/j.ajodo.2012.09.003. PMid:23540633.

12. Streva AM, Cotrim-Ferreira FA, Garib DG, Carvalho PE. Are torque values of preadjusted brackets precise? J Appl Oral Sci. 2011 Aug;19(4):313-7. http://dx.doi.org/10.1590/S167877572011005000003. PMid:21956587.

13. Arreghini A, Lombardo L, Mollica F, Siciliani G. Torque expression capacity of 0.018 and 0.022 bracket slots by changing archwire material and cross section. Prog Orthod. 2014 Sep;15(1):53. http://dx.doi.org/10.1186/s40510-014-0053-x. PMid:25329505.

14. Alrejaye N, Pober R, Giordano R 2nd. Torsional strength of computer-aided design/computer-aided manufacturing-fabricated esthetic orthodontic brackets. Angle Orthod. 2017 Jan;87(1):125-30. http://dx.doi.org/10.2319/040416-267.1. PMid:27403781.

15. Vhanbatte RS, Uddanwadiker RV, Patil P. Evaluation of torsional strength of ceramic brackets produced by arch wire twisting moment. International Journal on Mechanical Engineering and Robotics. 2014;2(4):33-7.

16. Nishio C, Mendes AM, Almeida MA, Tanaka E, Tanne K, Elias CN. Evaluation of esthetic brackets' resistance to torsional forces from the archwire. Am J Orthod Dentofacial Orthop. 2009 Jan;135(1):428. http://dx.doi.org/10.1016/j.ajodo.2007.04.036. PMid:19121499.

17. Archambault A, Lacoursiere R, Badawi H, Major PW, Carey J, Flores-Mir C. Torque expression in stainless steel orthodontic brackets. A systematic review. Angle Orthod. 2010 Jan;80(1):201-10. http://dx.doi.org/10.2319/080508-352.1. PMid:19852662. 
18. Major TW, Carey JP, Nobes DS, Heo G, Major PW. Mechanical effects of third-order movement in selfligated brackets by the measurement of torque expression. Am J Orthod Dentofacial Orthop. 2011 Jan;139(1):e31-44. http://dx.doi.org/10.1016/j.ajodo.2010.04.029. PMid:21195255.

19. Lohbauer U, Amberger G, Quinn GD, Scherrer SS. Fractographic analysis of a dental zirconia framework: a case study on design issues. J Mech Behav Biomed Mater. 2010 Nov;3(8):623-9. http://dx.doi.org/10.1016/j.jmbbm.2010.07.004. PMid:20826369.

20. Aknin PC, Nanda RS, Duncanson MG Jr, Currier GF, Sinha PK. Fracture strength of ceramic brackets during arch wire torsion. Am J Orthod Dentofacial Orthop. 1996 Jan;109(1):22-7. http://dx.doi.org/10.1016/S0889-5406(96)70159-2. PMid:8540476.

21. Ghafari J. Problems associated with ceramic brackets suggest limiting use to selected teeth. Angle Orthod. 1992;62(2):145-52. PMid:1626749.

22. Swartz ML. Ceramic brackets. J Clin Orthod. 1988 Feb;22(2):82-8. PMid:3075208.

23. Holt MH, Nanda RS, Duncanson MG Jr. Fracture resistance on ceramic brackets during arch wire torsion. Am J Orthod Dentofacial Orthop. 1991 Apr;99(4):287-93. http://dx.doi.org/10.1016/08895406(91)70010-T. PMid:2008887.

24. Nikolai RJ. Bioengineering analysis of orthodontic mechanics: Philadelphia: Lea \& Febiger; 1985. p. 299-305

\section{CONFLICTS OF INTERESTS}

The authors declare no conflicts of interest.

\section{${ }^{*}$ CORRESPONDING AUTHOR}

Ana Rosa Costa, UNIARARAS/FHO - Fundação Hermínio Ometto, Programa de Pós-graduação em Ortodontia, Av. Dr. Maximiliano Baruto, 500, Jardim Universitário, 13607-339 Araras - SP, Brasil, e-mail: anarosacosta_1@hotmail.com

Received: May 3, 2019

Accepted: August 28, 2019 